Research article

\title{
Multilayered epithelium in a rat model and human Barrett's esophagus: Similar expression patterns of transcription factors and differentiation markers
}

\author{
Xiaoxin Chen*1,2,3, Rong Qin1, Ba Liu², Yan Ma1, Yinghao Su${ }^{4}$, \\ Chung S Yang', Jonathan N Glickman ${ }^{5}$, Robert D Odze ${ }^{5}$ and \\ Nicholas J Shaheen ${ }^{3}$
}

\begin{abstract}
Address: ${ }^{1}$ Cancer Research Program, Julius L. Chambers Biomedical/Biotechnology Research Institute, North Carolina Central University, 700 George Street, Durham, NC 27707, USA, ${ }^{2}$ Susan Lehman Cullman Laboratory for Cancer Research, Department of Chemical Biology, Ernest Mario School of Pharmacy, Rutgers, The State University of New Jersey, Piscataway, NJ 08854, USA, ${ }^{3}$ Center of Esophageal Diseases and Swallowing, Division of Gastroenterology and Hepatology, University of North Carolina at Chapel Hill, Chapel Hill, NC 27599, USA, ${ }^{4}$ Department of Medicine and Center for Health Services Research, Vanderbilt University Medical Center, Nashville, TN 37232, USA and ${ }^{5}$ Department of Pathology, Brigham and Women's Hospital, Harvard Medical School, Boston, MA 02115, USA
\end{abstract}

Email: Xiaoxin Chen* - lchen@nccu.edu; Rong Qin - rqin@nccu.edu; Ba Liu - yma@nccu.edu; Yan Ma - yanma1972@gmail.com; Yinghao Su - yinghao.su@vanderbilt.edu; Chung S Yang - dwong@rci.rutgers.edu; Jonathan N Glickman - jglickman@partners.org; Robert D Odze - rodze@partners.org; Nicholas J Shaheen - nshaheen@med.unc.edu

* Corresponding author

Published: II January 2008

BMC Gastroenterology 2008, 8:I doi:10.1 186/147|-230X-8-I
Received: 7 August 2007

Accepted: II January 2008

This article is available from: http://www.biomedcentral.com//47/-230X/8/I

(C) 2008 Chen et al; licensee BioMed Central Ltd.

This is an Open Access article distributed under the terms of the Creative Commons Attribution License (http://creativecommons.org/licenses/by/2.0), which permits unrestricted use, distribution, and reproduction in any medium, provided the original work is properly cited.

\begin{abstract}
Background: In rats, esophagogastroduodenal anastomosis (EGDA) without concomitant chemical carcinogen treatment leads to gastroesophageal reflux disease, multilayered epithelium (MLE, a presumed precursor in intestinal metaplasia), columnar-lined esophagus, dysplasia, and esophageal adenocarcinoma. Previously we have shown that columnar-lined esophagus in EGDA rats resembled human Barrett's esophagus (BE) in its morphology, mucin features and expression of differentiation markers (Lab. Invest. 2004;84:753-765). The purpose of this study was to compare the phenotype of rat MLE with human MLE, in order to gain insight into the nature of MLE and its potential role in the development of BE.
\end{abstract}

Methods: Serial sectioning was performed on tissue samples from 32 EGDA rats and I 3 patients with established BE. Tissue sections were immunohistochemically stained for a variety of transcription factors and differentiation markers of esophageal squamous epithelium and intestinal columnar epithelium.

Results: We detected MLE in 56.3\% (18/32) of EGDA rats, and in all human samples. As expected, both rat and human squamous epithelium, but not intestinal metaplasia, expressed squamous transcription factors and differentiation markers (p63, Sox2, CKI4 and CK4) in all cases. Both rat and human intestinal metaplasia, but not squamous epithelium, expressed intestinal transcription factors and differentiation markers (Cdx2, GATA4, HNFI $\alpha$, villin and Muc2) in all cases. Rat MLE shared expression patterns of Sox2, CK4, Cdx2, GATA4, villin and Muc2 with human MLE. However, p63 and CKI4 were expressed in a higher proportion of rat MLE compared to humans.

Conclusion: These data indicate that rat MLE shares similar properties to human MLE in its expression pattern of these markers, not withstanding small differences, and support the concept that MLE may be a transitional stage in the metaplastic conversion of squamous to columnar epithelium in BE. 


\section{Background}

Barrett's esophagus (BE) is characterized by replacement of esophageal squamous epithelium by intestinalized columnar epithelium, most commonly due to chronic gastroesophageal reflux disease. Patients with BE are at increased risk for the development of esophageal adenocarcinoma, which is now the most rapidly increasing type of cancer in Western countries [1].

The pathogenesis of intestinal metaplasia (IM) in BE is poorly understood. For instance, theories regarding the origin of stem cells that give rise to intestinalized columnar epithelium include origin from esophageal squamous epithelium or the submucosal glands [2-5]. However, regardless of the site of origin, it is generally believed that pluripotent stem cells are triggered by inflammatory mediators and/or gastroesophageal refluxate to differentiate into intestinalized columnar epithelium $[5,6]$. Recent studies have focused on the potential roles of acid and bile, inflammatory mediators, and intestinal transcription factors in the pathogenesis of human BE [6-11]. Despite these efforts, the mechanism underlying the development of IM in BE remains unclear.

Multilayered epithelium (MLE), first described in 1997, is a hybrid epithelium that expresses cytokeratins of both squamous and columnar differentiation [12]. It is composed of multiple layers of cells that appear squamous in the basal portion and columnar in the superficial aspects. Several studies have shown that MLE is predominantly located at, or near, the neo-squamocolumnar junction in patients with BE. Multilayered epithelium has also been shown to correlate with BE and reflux esophagitis. Thus, it has been postulated that MLE may represent a transitional stage in the squamous to columnar transition in BE [1316].

In our laboratory, we utilized a rat surgical model to study BE. In this model, an esophagoduodenal anastomosis was created to induce gastroesophageal reflux. Sprague-Dawley rats subjected to this procedure developed esophageal adenocarcinoma [17]. Subsequently, we modified this procedure by performing an esophagogastroduodenal anastomosis (EGDA) in order to induce reflux of gastric and duodenal contents into the esophagus. Previous studies have shown that more than $50 \%$ of rats developed columnar-lined esophagus and adenocarcinoma 40 weeks after surgery [18]. In rats, MLE frequently also occurs at the neo-squamocolumnar junction, but occasionally in the mid-esophagus as well. Rat columnar-lined esophagus resembles human $\mathrm{BE}$ in its morphology, mucin features and in its expression of intestinal differentiation markers, such as keratin 7, keratin 20, Das-1, villin, and trefoil factor 1 [19].
The purpose of this study was to evaluate and compare MLE in our rat model to that in humans with established $\mathrm{BE}$, in order to gain further insight into the role of MLE in the development of BE. To perform this study, serial paraffin-embedded esophageal tissue sections from 32 EGDA rats were evaluated for expression patterns of transcription factors and differentiation markers of esophageal squamous epithelium and intestinal columnar epithelium not previously evaluated. Mucosal biopsy samples containing MLE from 13 human patients with established BE were also studied for comparison with the rat samples.

\section{Methods \\ Tissue samples}

Esophagogastroduodenal anastomosis was performed on 32 rats as described previously. [18] In brief, a surgical anastomosis was created between the gastroesophageal junction and the duodenum, on the antimesenteric border, with accurate mucosal to mucosal opposition, in 8week-old male Sprague-Dawley rats. The animals were treated with iron dextran $(4 \mathrm{mg} \mathrm{Fe} / \mathrm{kg} /$ week, i.p.) for 40 weeks. After the animals were sacrificed by $\mathrm{CO} 2$ asphyxiation, the esophagus was removed, fixed in $10 \%$ buffered formalin, Swiss-rolled, processed, and embedded in paraffin. Serial sections of tissue blocks from all 32 rats (300 to 500 sections per block) were then made for this study.

For comparison, coded (with all identifiers removed) archival formalin-fixed paraffin-embedded esophageal mucosal biopsies from 13 patients with MLE in BE were obtained from the files of the Department of Pathology, Brigham and Women's Hospital, Boston, MA. The study protocol was approved by the Institutional Review Board. Ten serial sections of each case were used in this study. Tissue sections from these 13 patients were specifically selected because they all contained MLE, as described previously [16].

\section{Pathological evaluation}

In rat tissues, one out of every twenty serial tissue sections was stained with hematoxylin and eosin, and then counterstained with Alcian blue at $\mathrm{pH} 2.5$. Tissue sections were evaluated for the presence of BE and MLE [19]. In brief, BE was characterized by the occurrence of IM, which was defined by the presence of goblet cells in the esophagus. Multilayered epithelium consists of 4 to 8 layers of cells that show squamous differentiation in the basal portion and columnar differentiation in the superficial layers. Serial sections that contained MLE were identified and selected for immunohistochemical staining.

Tissue sections of human samples were simultaneously stained with $H \& E$ and the presence of BE and MLE was confirmed. The presence or absence of squamous epithelium was also noted. 


\section{Immunohistochemical staining}

The following four groups of markers were studied (Table 1): (1) squamous transcription factors (p63, Sox2); (2) squamous differentiation markers (CK14, CK4); (3) intestinal transcription factors (Cdx2, GATA4, HNF1 $\alpha$ ); and (4) intestinal differentiation markers (villin, Muc2).

Briefly, paraffin-embedded tissue sections were deparaffinized, rehydrated, and pretreated by heating the slides for 5-10 min in $10 \mathrm{mM}$ citrate buffer. Immunohistochemical staining was performed with the ABC kit (Vector Labs, Capenteria, CA) according to the manufacturer's instructions. The sources of the primary antibodies, catalogue numbers, and working concentrations are listed in Table 1. Normal serum or phosphate buffered saline were used instead of the primary antibodies, as negative controls. Both positive and negative control slides were processed in parallel. Alcian blue staining (1\% in 3\% acetic acid, $\mathrm{pH} 2.5$, for $10 \mathrm{~min}$ ) was performed after immunohistochemical staining on the same slides to visualize cells that produce acidic mucin.

Immunohistochemical staining for each marker was scored by one pathologist (R.Q.) as either positive or negative in the epithelium of interest. Areas of squamous epithelium, MLE and IM were scored separately. For analysis of p63, Sox2, Cdx2, GATA4, and HNF1 $\alpha$, epithelium with strong nuclear staining was counted as positive. Cytoplasmic staining of Cdx2 was also noted. Cytoplasmic staining was counted as positive for analysis of CK4, CK14, villin and Muc2. The frequency of positive staining for each marker in each epithelial type was then calculated (Table 2).

\section{Statistical analysis}

Statistical analysis was conducted with Fisher exact test for frequency data. For each immunohistochemical stain, the frequency of positive staining between rat and human MLE was compared.

\section{Results \\ Histopathology of rat and human samples}

Twenty nine EGDA rats (29/32, 90.6\%) contained BE, defined by the presence of IM in the esophagus. Multilayered epithelium was detected in 18 of 32 (56.3\%) EGDA rats. The mean number of MLE foci per rat was 2.4 (range 1 to 6$)$. Most MLE foci (91\%) were located at the neosquamocolumnar junction, whereas fewer were located distant from the junction, or in the mid-esophagus. The morphologic features of MLE in the rat model closely resembled that of human patients $[14,16,19]$.

Human samples containing MLE were intentionally selected for this study. In addition, eleven samples also had squamous epithelium within their BE biopsies.

\section{Expression of squamous transcription factors and differentiation markers in rat and human samples (Figure I; Table 2)}

Both rat and human squamous epithelium uniformly expressed squamous transcription factors (p63 and Sox2) and differentiation markers (CK14 and CK4) in all cases (Figure 1A, D, G, J, M, P, S, V). P63 and Sox2 were both expressed in the nuclei of squamous epithelial cells in the basal cell layer. CK14 was expressed in the cytoplasm of basal cells, and CK4 in suprabasal cells.

Neither rat nor human IM expressed any of these transcription factors or differentiation markers (Figure 1C, F, I, L, O, R, U, X).

Both rat and human MLE expressed squamous transcription factor, Sox2, in the nuclei of basal cell layer of all cases (Figure 1E, Q), similar to squamous epithelium. p63 was expressed in $100 \%(85 / 85)$ of rat MLE (Figure 1B). However, only $38.5 \%$ (5/13) of human MLE (Figure $1 \mathrm{~N}$ ) expressed p63 ( $\mathrm{p}<0.0001 v$ s. rat MLE).

Of the two squamous differentiation markers (CK14 and CK4), CK14 was expressed in basal cells of rat MLE in all cases, similar to squamous epithelium (Figure $1 \mathrm{H}$ ). However, in human MLE, CK14 was negative in all 13 cases ( $\mathrm{p}$ $<0.0001$, vs. rat MLE; Figure 1T). CK4 was expressed in $54.5 \%(30 / 55)$ of rat MLE (Figure 1K), and in 30.8\% (4/ 13) of human MLE (Figure 1W). Such a difference was not statistically significant $(\mathrm{p}>0.05)$.

\section{Expression of intestinal transcription factors and differentiation markers in rat and human samples (Figure 2; Table 2)}

Neither rat nor human squamous epithelium expressed any of the intestinal transcription factors (Cdx2, GATA4 and $H N F 1 \alpha$ ) and differentiation markers (villin and Muc2) (figures not shown). However, both rat IM (Figure 2B, D, F, H) and human IM (Figure 2J, L, N, P) expressed all intestinal markers studied, except for one case of human IM in which GATA4 was not expressed.

Rat MLE did not express Cdx2, GATA4, and HNF1 $\alpha$ (Figure $2 \mathrm{~A}, \mathrm{C}, \mathrm{E}$ ) in any of the cases. Similar to rat MLE, human MLE did not express GATA4 and Muc2 (Figure 2K, $\mathrm{M})$. Interestingly although $\mathrm{Cdx} 2$ was not expressed in the nuclei in any cases, it was detected in the cytoplasm of two cases (Figure 2I).

Villin, an intestinal differentiation marker, was expressed in $26.8 \%(15 / 56)$ of rat MLE (Figure $2 \mathrm{G}$ ), and in $15.4 \%$ (2/13) of human MLE (Figure 2O). Such a difference was not statistically significant $(\mathrm{p}>0.05)$. 
Table I: Transcription factors and differentiation markers used in this study

\begin{tabular}{|c|c|c|c|c|c|}
\hline Antigen & Description & Expression Pattern & Antibody Source & Catalogue No. & Conc. \\
\hline p63 & $\begin{array}{l}\text { Transcription factor essential for } \\
\text { squamous epithelium }\end{array}$ & $\begin{array}{l}\text { Nuclei of basal and parabasal } \\
\text { squamous cells }\end{array}$ & $\begin{array}{l}\text { Santa Cruz Biotechnology } \\
\text { (Santa Cruz, CA) }\end{array}$ & sc-843I (mouse mAb) & $0.2 \mu \mathrm{g} / \mathrm{ml}$ \\
\hline $\begin{array}{l}\text { Sox2 (SRY-related HMG } \\
\text { box gene 2) }\end{array}$ & $\begin{array}{l}\text { Transcription factor essential for } \\
\text { upper gastrointestinal epithelium }\end{array}$ & $\begin{array}{l}\text { Nuclei of epithelial cells in oral cavity, } \\
\text { esophagus and stomach }\end{array}$ & Santa Cruz Biotechnology & sc- 17320 (goat pAb) & $4 \mu \mathrm{g} / \mathrm{ml}$ \\
\hline CKI4 (cytokeratin 14) & Squamous differentiation marker & Cytoplasm of basal squamous cells & $\begin{array}{l}\text { Novocastra Laboratories } \\
\text { Ltd. (Newcastle upon Tyne, } \\
\text { UK) }\end{array}$ & NCL-LL002 (mouse mAb) & $1: 40$ \\
\hline CK4 (cytokeratin 4) & Squamous differentiation marker & $\begin{array}{l}\text { Cytoplasm of parabasal squamous } \\
\text { cells }\end{array}$ & $\begin{array}{l}\text { Sigma-Aldrich (St. Louis, } \\
\text { MO) }\end{array}$ & C5I76 (mouse mAb) & $1: 500$ \\
\hline $\begin{array}{l}\text { Cdx2 (caudal-related } \\
\text { homeobox 2) }\end{array}$ & Intestinal transcription factor & $\begin{array}{l}\text { Nuclei (and occasionally cytoplasm) } \\
\text { of columnar and goblet cells }\end{array}$ & BioGenex (San Ramon, CA) & MU392-UC (mouse mAb) & $1: 50$ \\
\hline $\begin{array}{l}\text { GATA4 (GATA-binding } \\
\text { protein 4) }\end{array}$ & Intestinal transcription factor & Nuclei of columnar and goblet cells & Santa Cruz Biotechnology & sc-1237 (goat pAb) & $0.25 \mu \mathrm{g} / \mathrm{ml}$ \\
\hline Villin & Intestinal differentiation marker & $\begin{array}{l}\text { Cytoplasm of columnar and goblet } \\
\text { cells }\end{array}$ & NeoMarkers (Fremont, CA) & MS-I 499 (mouse mAb) & $5 \mu \mathrm{g} / \mathrm{ml}$ \\
\hline Muc2 (mucin 2) & Intestinal differentiation marker & Cytoplasm of goblet cells & Santa Cruz Biotechnology & sc-15334 (rabbit pAb) & l:500 \\
\hline
\end{tabular}


Table 2: Expression of transcription factors and differentiation markers in tissue samples from EGDA rats and humans

\begin{tabular}{|c|c|c|c|c|c|c|}
\hline \multirow[t]{2}{*}{ Antigen } & \multicolumn{3}{|c|}{$\begin{array}{c}\text { EGDA Rat Samples } \\
\text { No. of positively stained foci/No. of total foci (\%) }\end{array}$} & \multicolumn{3}{|c|}{$\begin{array}{c}\text { Human Biopsy Samples } \\
\text { No. of positively stained foci/No. of total foci (\%) }\end{array}$} \\
\hline & $\begin{array}{l}\text { Squamous } \\
\text { epithelium }\end{array}$ & MLE & $\begin{array}{l}\text { Intestinal } \\
\text { metaplasia }\end{array}$ & $\begin{array}{l}\text { Squamous } \\
\text { epithelium }\end{array}$ & MLE & $\begin{array}{l}\text { Intestinal } \\
\text { metaplasia }\end{array}$ \\
\hline$p 63^{a}$ & $128 / 128(100 \%)$ & $85 / 85$ (100\%) & $0 / 142(0 \%)$ & II/II (100\%) & $5 / 13$ (38.5\%) & $0 / 3(0 \%)$ \\
\hline Sox2 & $114 / 114$ (100\%) & $71 / 71$ (100\%) & $0 / 128(0 \%)$ & $11 / 11$ (100\%) & $13 / 13(100 \%)$ & $0 / 3(0 \%)$ \\
\hline $\mathrm{CK} / 4^{\mathrm{a}}$ & $113 / 113(100 \%)$ & $76 / 76(100 \%)$ & $0 / 139(0 \%)$ & $1 \mathrm{I} / \mathrm{I}(100 \%)$ & $0 / 13(0 \%)$ & $0 / 3(0 \%)$ \\
\hline CK4 & $116 / 116(100 \%)$ & $30 / 55(54.5 \%)$ & $0 / 129(0 \%)$ & II/II (100\%) & $4 / 13$ (30.8\%) & $0 / 3(0 \%)$ \\
\hline $\mathrm{Cd} \times 2$ & $0 / 114(0 \%)$ & $0 / 77(0 \%)$ & |27/| 27 (100\%) & $0 / 1 ।(0 \%)$ & $2 / 13$ (I5.4\%) & $3 / 3(100 \%)$ \\
\hline GATA4 & $0 / 114(0 \%)$ & $0 / 70(0 \%)$ & $130 / 130$ (100\%) & $0 / 11(0 \%)$ & $0 / 13(0 \%)$ & $2 / 3(66.7 \%)$ \\
\hline $\mathrm{HNFI} \alpha$ & $0 / 100(0 \%)$ & $0 / 54(0 \%)$ & III/III (100\%) & N/A & N/A & $\mathrm{N} / \mathrm{A}$ \\
\hline Villin & $0 / 115(0 \%)$ & $15 / 56$ (26.8\%) & 133/I33 (100\%) & $0 / 11(0 \%)$ & $2 / 13$ (I5.4\%) & $3 / 3(100 \%)$ \\
\hline Muc2 & $0 / 114(0 \%)$ & $0 / 75(0 \%)$ & 129/129 (100\%) & $0 / 11(0 \%)$ & $0 / 13(0 \%)$ & $3 / 3(100 \%)$ \\
\hline
\end{tabular}

a Statistically significant difference between rat and human MLE $(p<0.0001)$.

\section{Discussion}

Multilayered epithelium, a hybrid epithelium consisting of squamous cells in the basal portion and columnar cells in the superficial layers, was first described in esophageal biopsies in patients with BE [16]. Human MLE expressed differentiation markers of both squamous and intestinal columnar epithelium, suggesting that it might represent a transitional stage in the metaplastic conversion of squamous to columnar epithelium in BE $[12,14]$. In this study, we compared the phenotype of rat MLE versus human MLE in order to gain further insight into the nature of MLE, and its potential role in the development of BE.
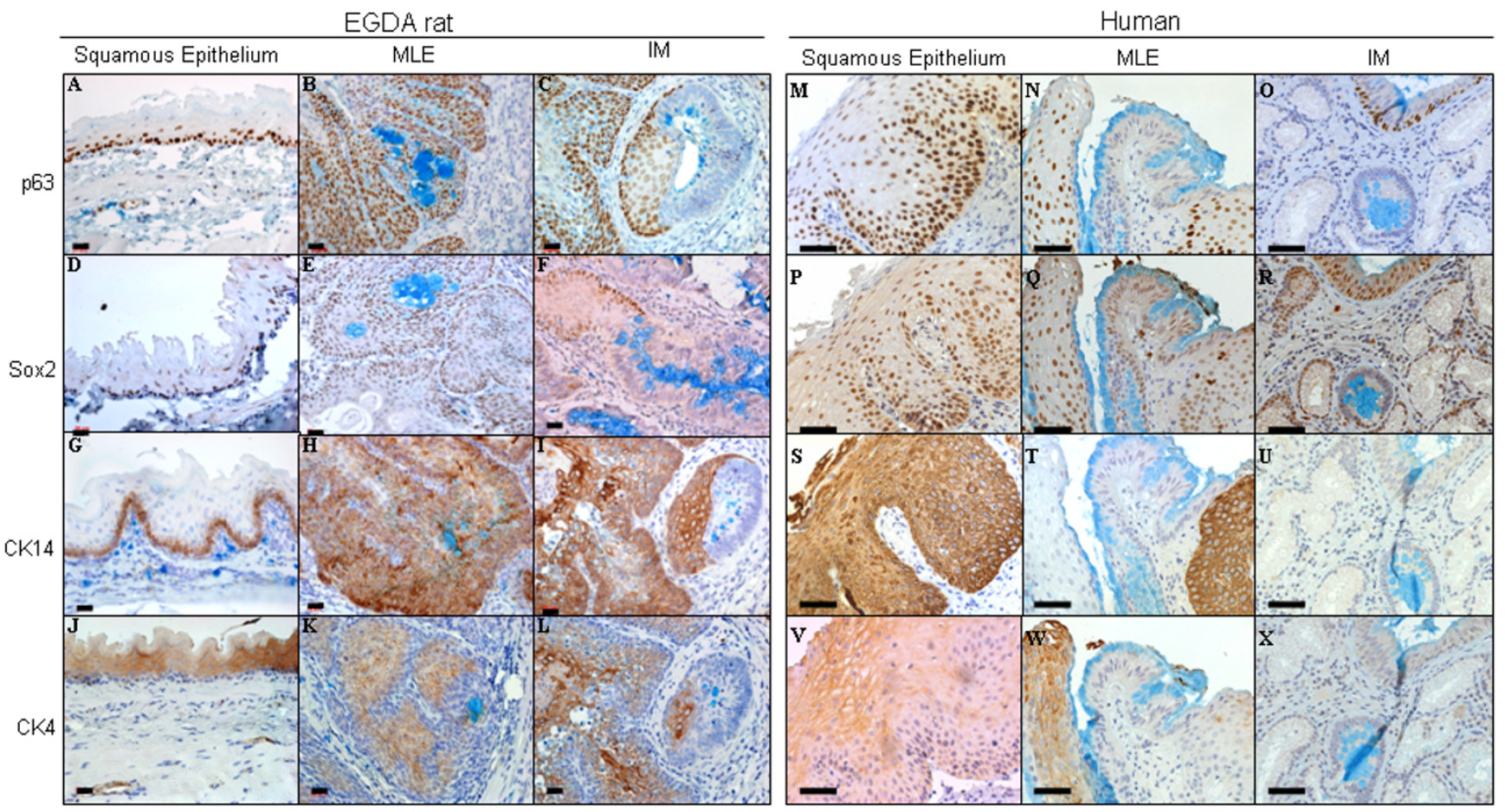

Figure I

Expression of squamous transcription factors (p63, Sox2) and differentiation markers (CK4, CkI4) in squamous epithelium, MLE and IM of EGDA rats and humans. All the tissue sections were stained immunohistochemically with a specific antibody, and then histochemically with Alcian blue. Light blue: Alcian blue staining of acidic mucin; dark blue: hematoxylin staining for nuclei; dark brown: immunohistochemical staining. Size bar equals $20 \mu \mathrm{m}$ in rat samples, or $40 \mu \mathrm{m}$ in human samples. 

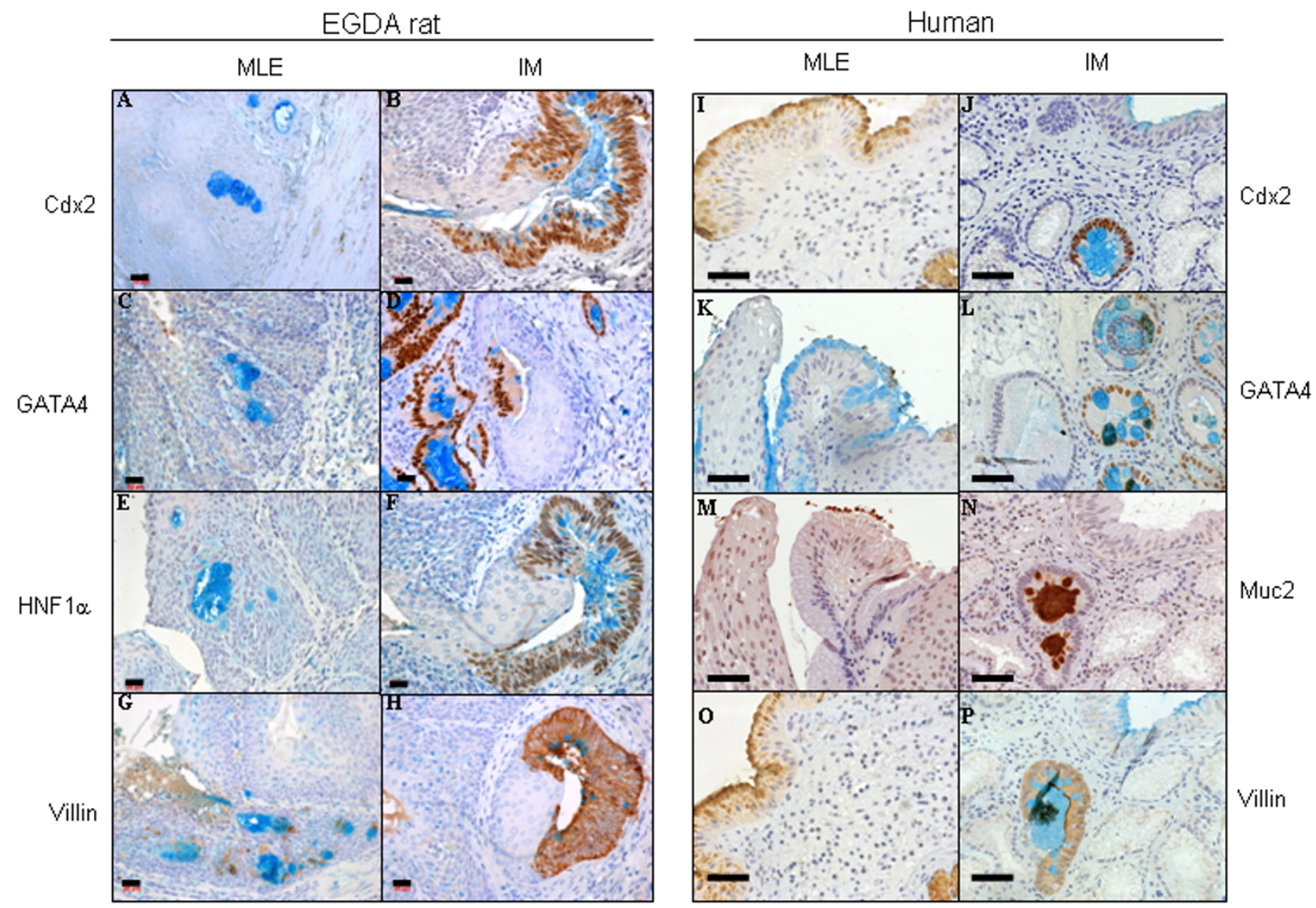

Figure 2

Expression of intestinal transcription factors (Cdx2, GATA4, HNFI $\alpha$ ) and differentiation markers (villin, Muc2) in MLE and IM of EGDA rats and humans. All the tissue sections were stained immunohistochemically with a specific antibody, and then histochemically with Alcian blue. Light blue: Alcian blue staining of acidic mucin; dark blue: hematoxylin staining for nuclei; dark brown: immunohistochemical staining. Size bar equals $20 \mu \mathrm{m}$ in rat samples, or $40 \mu \mathrm{m}$ in human samples.

We focused on squamous transcription factors (p63, Sox2) and differentiation markers (CK4, CK14), and intestinal transcription factors (Cdx2, GTAT4, HNF1 $\alpha$ ) and differentiation markers (villin, Muc2). Transcription factors represent "master switch" genes, which regulate expression of differentiation-related molecules with both structural and functional specificity, and, thus, mediate metaplasia. Using immunohistochemical staining we found that both rat and human MLE simultaneously expressed markers of both squamous and intestinal differentiation, and that with minor exceptions, rat and human MLE shared similar expression patterns of these markers. For instance, we found that rat MLE is more likely to express p63 and CK14 compared to human MLE.

The squamous transcription factors and differentiation markers evaluated in this study include p63, Sox2, CK4 and CK14. P63 is a critical initiator of epithelial stratification and a key regulator of cell adhesion and survival in progenitor cells in squamous epithelium [20-22]. In mouse esophagus, when basal cells become differentiated, p63 is down-regulated and eventually turned off in terminally differentiated superficial cells $[15,23]$. In p63deficient mice, embryonic esophageal epithelium appears columnar containing both ciliated and goblet-like cells [24]. Previous studies have shown that p63 is expressed in the basal and suprabasal cell layers, and in submucosal glands, of human esophageal squamous epithelium $[15,25]$. p63 in esophageal epithelial cells was downregulated when they were exposed to bile and acid [26]. In this study, p63 was detected in all cases of rat MLE, but in only $38.5 \%(5 / 13)$ of human MLE $(p<0.0001)$. This result suggests that rat and human MLE show differences in their native esophageal epithelium, and that basal cells of rat 
MLE maintain a higher degree of "squamous" differentiation compared to rat MLE. It is known that rat esophagus is covered by keratinized squamous epithelium and human esophagus by non-keratinized squamous epithelium.

As a member of the $S r y$-like high mobility group domain protein family, Sox 2 may play an important role in the development of the upper gastrointestinal tract. It is expressed in the pharynx, esophagus, and stomach of chicken gut, but not in the lower gastrointestinal tract, where $\mathrm{Cdx} 1$ and $\mathrm{Cdx} 2$ are present and play an important role in cell differentiation $[27,28]$. Sox 2 mutations are associated with esophageal atresia in anophthalmiaesophageal-genital syndrome [29], and its down-regulation is associated with intestinal metaplasia in the stomach [30,31]. Hypomorphic Sox2 mice developed metaplastic changes of morphology and gene expression in the esophagus [32]. Our data showed that Sox2 was expressed in both rat and human MLE in all cases. In intestinal metaplasia, Sox2 was negative in both rat and human samples. Recently, Sox2 was reported to be silenced by promoter methylation in intestinal-type gastric cancer [33]. Further studies are needed to understand the mechanisms by which Sox 2 is turned off in metaplastic columnar epithelium.

CK4 and CK14 are differentiation markers of esophageal squamous epithelium. CK14 is typically expressed in basal cells and CK4 in parabasal cells [34]. Interestingly, in our study, CK14 was not expressed in human MLE, but it was expressed in all cases of rat MLE. This expression pattern was similar to that of p63 in rat and human MLE, likely due to the fact that CK14 is a transcriptional target of p63 [35]. Nevertheless, these data support the theory that rat MLE maintains a higher level of "squamous" differentiation compared to human MLE. In the presence of gastroesophageal reflux, human esophagus was more likely to lose squamous differentiation features.

We also evaluated intestinal transcription factors (Cdx2, GATA4 and HNF1 $\alpha$ ) and differentiation markers (villin and Muc2). As a member of the Caudal-related homeobox gene family, Cdx2 is important for skeletal and intestinal development. Cdx2 plays an important regulatory role in the development of intestinal metaplasia in the foregut, and in cancer development in the colon $[36,37]$. Cdx2 is normally not expressed in squamous cells of the normal human esophagus. However, one previous study showed that a low level of $C d x 2$ mRNA was detected in biopsy samples of esophageal squamous epithelium in patients with esophagitis $[11,38]$. In $\mathrm{BE}, \mathrm{Cdx} 2$ is expressed in goblet and non-goblet cells [39]. In fact, several Cdx2-regulated genes are known "markers" of $\mathrm{BE}$, such as villin, guanylate cyclase $\mathrm{C}$, and sucrase isomaltase [40-42]. We recently demonstrated that treatment of esophageal epithelial cells with acid, bile acids or both resulted in promoter demethylation and activation of $C d x 2$ [43]. In this study, Cdx2 was negative in all rat MLE samples, which suggests that $\mathrm{Cdx} 2$ is not expressed at an early stage of columnar metaplasia. However, in human MLE, two cases expressed Cdx2 in the cytoplasm, although none of them showed nuclear expression. Similarly, cytoplasmic expression of $\mathrm{Cdx} 2$ has been reported in the columnar epithelium of colon, bile duct and stomach [44-46]. The significance of cytoplasmic accumulation of $\mathrm{Cdx} 2$ is still unclear.

GATA4 belongs to a subfamily of the GATA transcription factor family involved in differentiation of mesoderm and endoderm-derived tissues. GATA4, 5 and 6 are expressed in the stomach and small intestine, but not in the esophagus [47-49]. HNF1 $\alpha$ is a liver-enriched homeodomaincontaining transcription factor, which regulates many genes in liver and pancreas [50,51]. Intestinal transcriptional factors (GATA4, HNF1 $\alpha$, and Cdx2) have been shown to play cooperative roles in regulating the expression of several marker genes in intestinal epithelium and human BE $[40,50,51]$. In this study, neither rat nor human MLE expressed GATA4 or HNF1 $\alpha$, suggesting that GATA4 and HNF1 $\alpha$ are probably not involved at an early stage of conversion from squamous to columnar epithelium in the esophagus.

Villin is an actin-bundling protein and a marker of human BE [19,52-54]. Muc2 is a differentiation marker of intestinal and tracheobronchial goblet cells [55], and is known to be regulated by $C d x 2$ in esophageal epithelial cells $[9,43]$. In this study, villin was expressed in a small percentage of rat and human MLE, whereas Muc2 was not expressed in either type of tissues. These data suggest that the mucinous cells in MLE do not possess some biological properties of fully developed goblet cells. It is possible that, during the metaplastic conversion of squamous to columnar epithelium, villin is expressed at an early phase, whereas Muc2 is expressed only when phenotypically mature goblet cells develop. Although villin is a possible transcriptional target of Cdx2 [41], our data suggest that other factors may regulate its expression in MLE.

The mechanism of intestinal metaplasia is still unclear. Our data in rat model strongly support the theory that stem cells reside in the esophagus. Three theories have been proposed for the development of intestinal metaplasia in human BE. The de novo metaplasia theory proposes that the stem cells of inflamed squamous epithelium are stimulated by reflux to undergo columnar metaplasia. The transitional zone metaplasia theory suggests that epithelial cells at the squamocolumnar junction colonize the gastric cardia or distal esophagus in response to reflux. 
The esophageal gland duct cell metaplasia theory proposes that stem cells are located in the neck of submucosal gland ducts, and they are stimulated to expand upon deep ulceration of the mucosa and submucosa [5]. However, rats do not have submucosal glands or ducts in their esophagus, and rat MLE is commonly found in the midesophagus unrelated to the neo-squamocolumnar junction after EGDA surgery. Thus, development of MLE in EGDA rats supports pluripotent stem cells in the esophagus as the cellular origin of intestinal metaplasia. This hypothesis is consistent with previous studies suggesting gut regenerative cell lineage as the likely cellular origin of $\mathrm{BE}$ [56]. Although MLE is likely a precursor lesion of BE, it can not be excluded that MLE may be a distinct multidirectional differentiation type of epithelium, which may not develop into BE.

\section{Conclusion}

In summary, this study shows that rat MLE is similar to human MLE in the expression pattern of markers of squamous and intestinal differentiation. Further studies are warranted to determine how these markers are modulated by gastroesophageal reflux, and how they cooperate with each other to facilitate columnar metaplasia.

\section{Abbreviations}

BE: Barrett's esophagus; Cdx: caudal-related homeobox; CK: Cytokeratin; EGDA: Esophagogastroduodenal anastomosis; GATA4: GATA-binding protein 4; HNF1: Hepatocyte nuclear factor $1 \alpha$; IM: Intestinal metaplasia; MLE: Multilayered epithelium; Muc2: Mucin 2; Sox2: SRYrelated HMG box gene 2 .

\section{Competing interests}

The author(s) declare that they have no competing interests.

\section{Authors' contributions}

$\mathrm{XC}$ designed the study, participated in the data interpretation, and drafted the manuscript. RQ read the slides and performed the statistical analysis. BL and YM carried out the sectioning and immunostaining. YS, CSY, JNG, RDO, and NJS participated in the design of the study and the data interpretation. JNG and RDO also helped to draft the manuscript. All authors read and approved the final manuscript.

\section{Acknowledgements}

This project is supported by NIH grants CA75683, DK63650 and CA092077, and the Dave Brumitt Foundation.

\section{References}

I. Chen $X$, Yang CS: Esophageal adenocarcinoma: a review and perspectives on the mechanism of carcinogenesis and chemoprevention. Carcinogenesis 200I, 22(8): III9-II 29.
2. Guillem PG: How to make a Barrett esophagus: pathophysiology of columnar metaplasia of the esophagus. Dig Dis Sci 2005, 50(3):4I5-424.

3. Orlando RC: Pathogenesis of reflux esophagitis and Barrett's esophagus. Med Clin North Am 2005, 89(2):219-4I, vii.

4. Shaheen NJ: Advances in Barrett's esophagus and esophageal adenocarcinoma. Gastroenterology 2005, I 28(6): I 554- 1566.

5. Jankowski JA, Harrison RF, Perry I, Balkwill F, Tselepis C: Barrett's metaplasia. Lancet 2000, 356(9247):2079-2085.

6. Fitzgerald RC: Barrett's oesophagus and oesophageal adenocarcinoma: how does acid interfere with cell proliferation and differentiation? Gut 2005, 54 Suppl I:i2I-6.

7. Wong NA, Wilding J, Bartlett S, Liu Y, Warren BF, Piris J, Maynard N, Marshall R, Bodmer WF: CDXI is an important molecular mediator of Barrett's metaplasia. Proc Natl Acad Sci U S A 2005, I 02(2I):7565-7570.

8. Tselepis C, Perry I, Dawson C, Hardy R, Darnton SJ, McConkey C, Stuart RC, Wright N, Harrison R, Jankowski JA: Tumour necrosis factor-alpha in Barrett's oesophagus: a potential novel mechanism of action. Oncogene 2002, 2 I(39):607I-608I.

9. Kazumori H, Ishihara S, Rumi MA, Kadowaki Y, Kinoshita Y: Bile acids directly augment caudal related homeobox gene $\mathbf{C d \times 2}$ expression in oesophageal keratinocytes in Barrett's epithelium. Gut 2006, 55(I):16-25.

10. Marchetti M, Caliot E, Pringault E: Chronic acid exposure leads to activation of the cdx2 intestinal homeobox gene in a longterm culture of mouse esophageal keratinocytes. I Cell Sci 2003, I I 6(Pt 8): I 429-| 436.

II. Eda A, Osawa H, Satoh K, Yanaka I, Kihira K, Ishino Y, Mutoh H, Sugano K: Aberrant expression of CDX2 in Barrett's epithelium and inflammatory esophageal mucosa. J Gastroenterol 2003, 38(I): 14-22.

12. Boch JA, Shields HM, Antonioli DA, Zwas F, Sawhney RA, Trier JS: Distribution of cytokeratin markers in Barrett's specialized columnar epithelium. Gastroenterology 1997, I I 2(3):760-765.

13. Upton MP, Nishioka NS, Ransil BJ, Rosenberg SJ, Puricelli WP, Zwas FR, Shields HM: Multilayered epithelium may be found in patients with Barrett's epithelium and dysplasia or adenocarcinoma. Dig Dis Sci 2006, 5 I (10): I 783-1790.

14. Glickman JN, Chen YY, Wang HH, Antonioli DA, Odze RD: Phenotypic characteristics of a distinctive multilayered epithelium suggests that it is a precursor in the development of Barrett's esophagus. Am J Surg Pathol 200 I, 25(5):569-578.

15. Glickman JN, Yang A, Shahsafaei A, McKeon F, Odze RD: Expression of p53-related protein p63 in the gastrointestinal tract and in esophageal metaplastic and neoplastic disorders. Hum Pathol 200I, 32(II): II57-II65.

16. Shields HM, Rosenberg SJ, Zwas FR, Ransil BJ, Lembo AJ, Odze R: Prospective evaluation of multilayered epithelium in Barrett's esophagus. Am J Gastroenterol 200I, 96(I 2):3268-3273.

17. Goldstein SR, Yang GY, Curtis SK, Reuhl KR, Liu BC, Mirvish SS, Newmark HL, Yang CS: Development of esophageal metaplasia and adenocarcinoma in a rat surgical model without the use of a carcinogen. Carcinogenesis 1997, 18(I I):2265-2270.

18. Chen X, Yang G, Ding WY, Bondoc F, Curtis SK, Yang CS: An esophagogastroduodenal anastomosis model for esophageal adenocarcinogenesis in rats and enhancement by iron overload. Carcinogenesis 1999, 20(9): I80I-1808.

19. Su Y, Chen X, Klein M, Fang M, Wang S, Yang CS, Goyal RK: Phenotype of columnar-lined esophagus in rats with esophagogastroduodenal anastomosis: similarity to human Barrett's esophagus. Lab Invest 2004, 84(6):753-765.

20. Koster MI, Kim S, Mills AA, DeMayo FJ, Roop DR: p63 is the molecular switch for initiation of an epithelial stratification program. Genes Dev 2004, 18(2): 126-131.

21. Koster MI, Kim S, Roop DR: P63 deficiency: a failure of lineage commitment or stem cell maintenance? J Investig Dermatol Symp Proc 2005, 10(2): 11 8-123.

22. Carroll DK, Carroll JS, Leong CO, Cheng F, Brown M, Mills AA, Brugge JS, Ellisen LW: p63 regulates an adhesion programme and cell survival in epithelial cells. Nat Cell Biol 2006, 8(6):55|-56|.

23. Daniely Y, Liao G, Dixon D, Linnoila RI, Lori A, Randell SH, Oren M, Jetten AM: Critical role of p63 in the development of a normal esophageal and tracheobronchial epithelium. Am J Physiol Cell Physiol 2004, 287(I):CI7I-8I. 
24. Yang A, Schweitzer R, Sun D, Kaghad M, Walker N, Bronson RT, Tabin C, Sharpe A, Caput D, Crum C, McKeon F: p63 is essential for regenerative proliferation in limb, craniofacial and epithelial development. Nature 1999, 398(6729):7|4-7|8.

25. Geddert H, Kiel S, Heep HJ, Gabbert HE, Sarbia M: The role of p63 and deltaNp63 (p40) protein expression and gene amplification in esophageal carcinogenesis. Hum Pathol 2003, 34(9):850-856.

26. Roman S, Petre A, Thepot A, Hautefeuille A, Scoazec JY, Mion F, Hainaut $P$ : Downregulation of $p 63$ upon exposure to bile salts and acid in normal and cancer esophageal cells in culture. Am J Physiol Gastrointest Liver Physiol 2007, 293(I):G45-53.

27. Ishii Y, Rex M, Scotting PJ, Yasugi S: Region-specific expression of chicken Sox 2 in the developing gut and lung epithelium: regulation by epithelial-mesenchymal interactions. Dev Dyn 1998, 2 I 3(4):464-475.

28. Kamachi Y, Uchikawa M, Kondoh H: Pairing SOX off: with partners in the regulation of embryonic development. Trends Genet 2000, I 6(4): 182-187.

29. Williamson KA, Hever AM, Rainger J, Rogers RC, Magee A, Fiedler Z, Keng WT, Sharkey FH, McGill N, Hill CJ, Schneider A, Messina M, Turnpenny PD, Fantes JA, van Heyningen V, FitzPatrick DR: Mutations in SOX2 cause anophthalmia-esophageal-genital (AEG) syndrome. Hum Mol Genet 2006, I 5(9): | 4 | 3-| 422.

30. Tsukamoto T, Inada K, Tanaka H, Mizoshita T, Mihara M, Ushijima T, Yamamura Y, Nakamura S, Tatematsu M: Down-regulation of a gastric transcription factor, Sox2, and ectopic expression of intestinal homeobox genes, $\mathrm{Cdx} I$ and $\mathrm{Cdx}$ 2: inverse correlation during progression from gastric/intestinal-mixed to complete intestinal metaplasia. J Cancer Res Clin Oncol 2004, | 30(3): | 35-|45.

31. Tsukamoto T, Mizoshita T, Mihara M, Tanaka H, Takenaka Y, Yamamura $Y$, Nakamura S, Ushijima T, Tatematsu M: Sox2 expression in human stomach adenocarcinomas with gastric and gastricand-intestinal-mixed phenotypes. Histopathology 2005, 46(6):649-658.

32. Que J, Okubo T, Goldenring JR, Nam KT, Kurotani R, Morrisey EE, Taranova O, Pevny LH, Hogan BL: Multiple dose-dependent roles for Sox 2 in the patterning and differentiation of anterior foregut endoderm. Development 2007, I 34(I 3):252 I-253 I.

33. Otsubo T, Akiyama $Y$, Yuasa $Y$ : Sox 2 inhibits growth of gastric epithelial cell lines through cell cycle arrest and apoptosis. Proc AACR 2007, 48:AI 239.

34. Viaene Al, Baert JH: Expression of cytokeratin mRNAs in normal human esophageal epithelium. Anat $\operatorname{Rec} 1995$, 24 I (I):88-98.

35. Romano RA, Birkaya B, Sinha S: A functional enhancer of keratin 14 is a direct transcriptional target of deltaNp63. J Invest Dermatol 2007, I 27(5): I |75-। I86.

36. Guo RJ, Suh ER, Lynch JP: The role of cdx proteins in intestinal development and cancer. Cancer Biol Ther 2004, 3(7):593-60I.

37. Silberg DG, Swain GP, Suh ER, Traber PG: CdxI and cdx2 expression during intestinal development. Gastroenterology 2000, I I 9(4):96I-97|.

38. Silberg DG, Furth EE, Taylor JK, Schuck T, Chiou T, Traber PG: CDXI protein expression in normal, metaplastic, and neoplastic human alimentary tract epithelium. Gastroenterology 1997, I | 3(2):478-486.

39. Groisman GM, Amar M, Meir A: Expression of the intestinal marker $\mathrm{Cdx2}$ in the columnar-lined esophagus with and without intestinal (Barrett's) metaplasia. Mod Pathol 2004, I 7(1 0): I 282-1288.

40. Boudreau F, Rings EH, van Wering HM, Kim RK, Swain GP, Krasinski SD, Moffett J, Grand RJ, Suh ER, Traber PG: Hepatocyte nuclear factor-I alpha, GATA-4, and caudal related homeodomain protein $\mathrm{Cdx} 2$ interact functionally to modulate intestinal gene transcription. Implication for the developmental regulation of the sucrase-isomaltase gene. J Biol Chem 2002, 277(35):31909-31917.

4I. Braunstein EM, Qiao XT, Madison B, Pinson K, Dunbar L, Gumucio DL: Villin: A marker for development of the epithelial pyloric border. Dev Dyn 2002, 224(I):90-102.

42. Park J, Schulz S, Waldman SA: Intestine-specific activity of the human guanylyl cyclase $\mathrm{C}$ promoter is regulated by $\mathrm{Cdx} 2$. Gastroenterology 2000, I I 9(I):89-96.
43. Liu T, Zhang X, So CK, Wang S, Wang P, Yan L, Myers R, Chen Z, Patterson AP, Yang CS, Chen X: Regulation of Cdx2 expression by promoter methylation, and effects of $\mathrm{Cdx} 2$ transfection on morphology and gene expression of human esophageal epithelial cells. Carcinogenesis 2007, 28(2):488-496.

44. Hinoi T, Loda M, Fearon ER: Silencing of CDX2 expression in colon cancer via a dominant repression pathway. J Biol Chem 2003, 278(45):44608-446I6.

45. Ishikawa A, Sasaki M, Ohira S, Ohta T, Oda K, Nimura Y, Chen MF Jan YY, Yeh TS, Nakanuma Y: Aberrant expression of CDX2 is closely related to the intestinal metaplasia and MUC2 expression in intraductal papillary neoplasm of the liver in hepatolithiasis. Lab Invest 2004, 84(5):629-638.

46. Satoh K, Mutoh H, Eda A, Yanaka I, Osawa H, Honda S, Kawata H, Kihira K, Sugano K: Aberrant expression of CDX2 in the gastric mucosa with and without intestinal metaplasia: effect of eradication of Helicobacter pylori. Helicobacter 2002, 7(3): 192-198.

47. Molkentin JD: The zinc finger-containing transcription factors GATA-4, -5, and -6. Ubiquitously expressed regulators of tissue-specific gene expression. J Biol Chem 2000, 275(50):38949-38952.

48. Jacobsen CM, Narita N, Bielinska M, Syder AJ, Gordon JI, Wilson DB: Genetic mosaic analysis reveals that GATA-4 is required for proper differentiation of mouse gastric epithelium. Dev Biol 2002, 24 I (I):34-46.

49. Sakamoto N, Fukuda K, Watanuki K, Sakai D, Komano T, Scotting PJ, Yasugi S: Role for cGATA-5 in transcriptional regulation of the embryonic chicken pepsinogen gene by epithelial-mesenchymal interactions in the developing chicken stomach. Dev Biol 2000, 223(I): 103-II3.

50. Odom DT, Zizlsperger N, Gordon DB, Bell GW, Rinaldi NJ, Murray HL, Volkert TL, Schreiber J, Rolfe PA, Gifford DK, Fraenkel E, Bell GI, Young RA: Control of pancreas and liver gene expression by HNF transcription factors. Science 2004, 303(5662): | 378- | 38|.

5I. Gregory PA, Lewinsky RH, Gardner-Stephen DA, Mackenzie PI: Regulation of UDP glucuronosyltransferases in the gastrointestinal tract. Toxicol Appl Pharmacol 2004, I 99(3):354-363.

52. Kumble S, Omary MB, Fajardo LF, Triadafilopoulos G: Multifocal heterogeneity in villin and Ep-CAM expression in Barrett's esophagus. Int J Cancer 1996, 66(I):48-54.

53. MacLennan AJ, Orringer MB, Beer DG: Identification of intestinal-type Barrett's metaplasia by using the intestine-specific protein villin and esophageal brush cytology. Mol Carcinog 1999, 24(2):137-143.

54. Regalado SP, Nambu $Y$, lannettoni MD, Orringer MB, Beer DG: Abundant expression of the intestinal protein villin in Barrett's metaplasia and esophageal adenocarcinomas. Mol Carcinog 1998, 22(3): 182-189.

55. Gendler SJ, Spicer AP: Epithelial mucin genes. Annu Rev Physiol 1995, 57:607-634.

56. Kumagai H, Mukaisho K, Sugihara H, Bamba M, Miyashita T, Miwa K, Hattori T: Cell kinetic study on histogenesis of Barrett's esophagus using rat reflux model. Scand J Gastroenterol 2003, 38(7):687-692.

\section{Pre-publication history}

The pre-publication history for this paper can be accessed here:

http://www.biomedcentral.com/1471-230X/8/1/prepub 